\title{
The Bainite Reaction Kinetics in Austempered Ductile Iron
}

\author{
Yu.N. Taran, K.I. Uzlov and A.Yu, Kutsov \\ Physical Metallurgy Department, State Metallurgical Academy of Ukraine, Prospekt Gagarina 4, \\ Dnepropetrovsk 320635, Ukraine
}

\begin{abstract}
Bainitic reaction kinetics in ductile iron contained according to Ukrainian standard (weight \%) 3.60 3.80 carbon, $2.60-2.80 \mathrm{Si}, \sim 0.12 \mathrm{Mn}, \sim 0.60 \mathrm{Cu}$ and additionally alloyed by Mo $(0.15-0.20)$ has been studied. It was found that the overall transformation kinefics becomes slower as transformation temperature increase. This is because more intensive redistribution of carbon into austenite at higher temperatures. Two austenites wiith different carbon content have been fixed and kinetics of their lattices parameters has been studied.
\end{abstract}

\section{EXPERIMENTAL}

The subject of present investigation is ductile iron containing (weight percent): $3.60-3.80$ carbon, $2.60-$ $2.80 \mathrm{Si}, \sim 0.12 \mathrm{Mn}, \sim 0.60 \mathrm{Cu}$ and additionally alloyed by $\mathrm{Mo}(0.15-0.20)$. Content of sulphur, magnesium and phosporus corresponds to Ukrainian standard (GOST 7293-85). Specimens austenitisation has been done in an electrically heated furnace with protective argon atmosphere at $950^{\circ} \mathrm{C}$ during one hour. Austempering was performed by rapid transferring of specimens to salt bath with mixture $\left(\mathrm{KNO}_{3}, \mathrm{NaNO}_{3}\right)$ and holding at $380^{\circ} \mathrm{C}, 350^{\circ} \mathrm{C}, 300^{\circ} \mathrm{C}$ for times from 5 to 120 minutes. After austempering the specimens were quenched into water. The temperature has been controlled automatically within accuracy range $\pm 3^{\circ} \mathrm{C}$. Austempered specimens have been ground and polished with diamond paste. The study has been realised by methods of optical microscopy, scanning electron microscopy, X-ray diffraction. Before optical and scanning electron microscopy specimens was etched by $5 \%$ nital.

\section{MICROSTRUCTURAL OBSERVATION}

At the initial stages of bainitic reaction at $380^{\circ} \mathrm{C}$ ( 5 -minutes holding) $\alpha$-phase has been mainly formed around graphite nodules (Fig. 1a). The amount of bainitic ferrite is much smaller in the peripherical volume of austenite. Bainitic sheaves in the periphery of eutectic austenite are much shorter and finer than that located in austenite near graphite nodules. This microstructure is typical for up to 30 minutes austempering at $380^{\circ} \mathrm{C}$. The amount of austenite has been reduced with austempering time increasing due to transformations in peripherical austenite volumes. Untransformed austenite fields have existed only in thin zone in the periphery of eutectic cells - so-called "white spot etching" (Fig. 1b). At the austempering time increasing to 45 minutes (Fig. 1c), amount of bainitic ferrite also increases due to transformation in peripherical austenite volume. Increasing of austempering time in the interval 45-120 minutes did not lead to the essential alteration of matrix structure. The examination of bainitic sheaves morphology shown that each sheaf consists of elipsoidal so-called sub-units, which have the same crystallographic orientation (Fig.1d) [1]. This morphology is specific for upper bainite and looks like bainite morphology in low carbon steels [1].

Bainite reaction at $350^{\circ} \mathrm{C}$ follows by the same way as at $380^{\circ} \mathrm{C}$. At the initial step of austempering bainite reaction has been mainly realised in the austenite volume near graphite nodules (during 5 minutes). The formation of bainite sheaves in the austenite-graphite interface has been clearly 


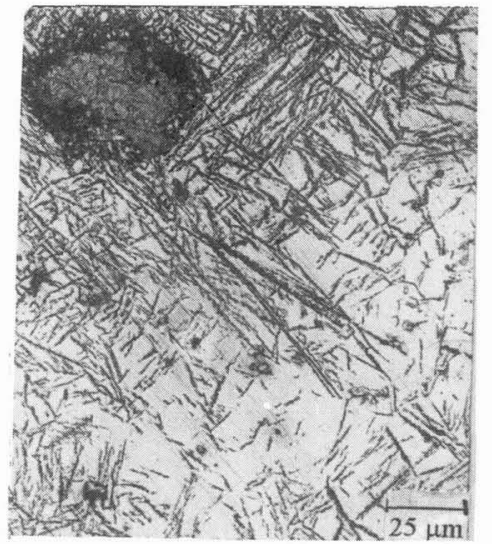

a

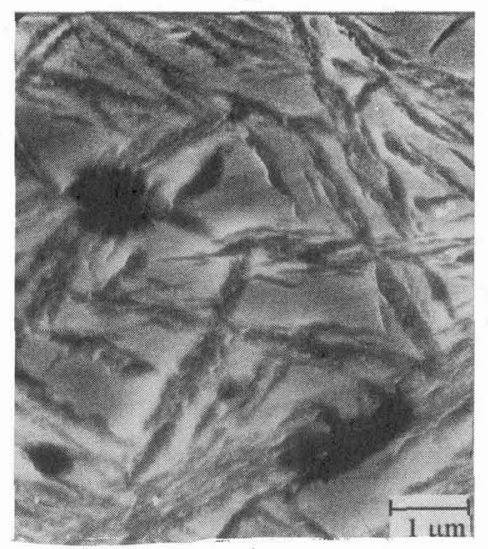

d

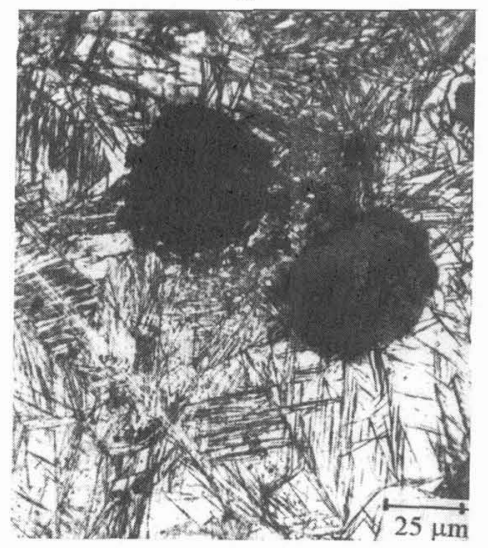

g

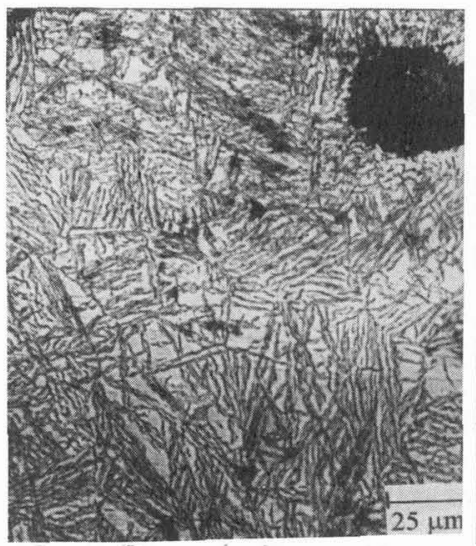

b

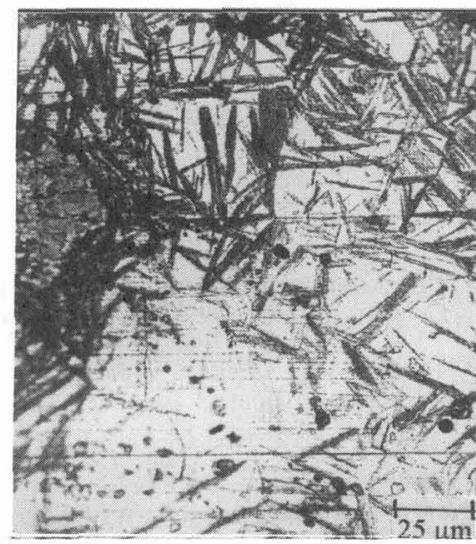

e

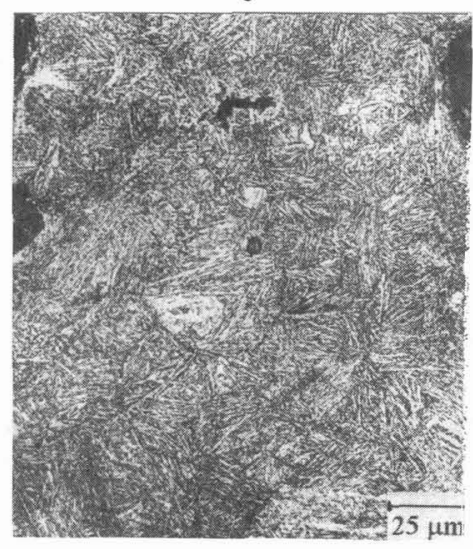

$\mathrm{h}$

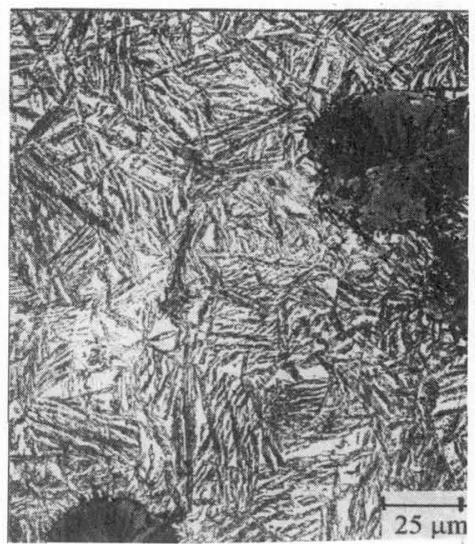

c

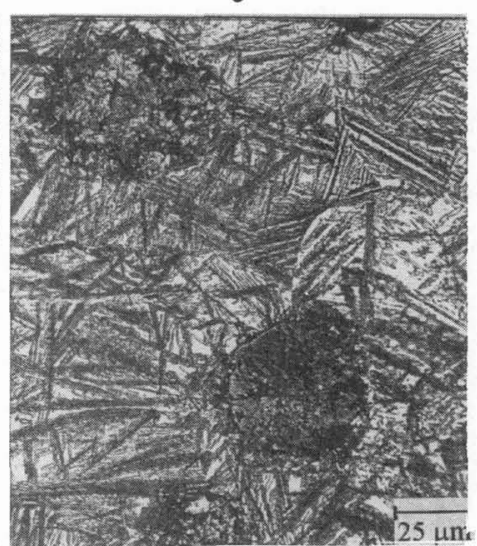

t

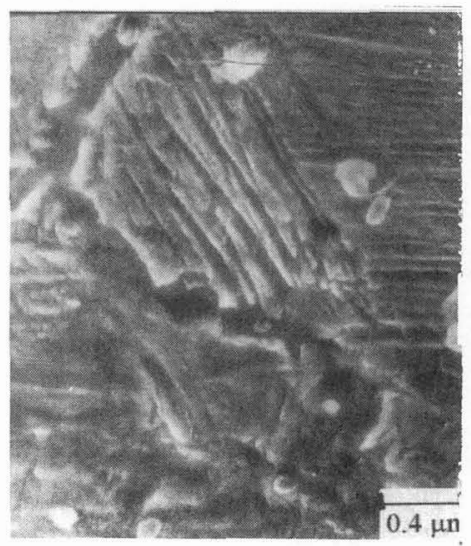

k

Fig.1. Bainite microstructures formed at different temperatures

a $-380^{\circ} \mathrm{C}, 5 \mathrm{~min} ; 380^{\circ} \mathrm{C}, \mathrm{b}-30 \mathrm{~min} ; 380^{\circ} \mathrm{C}, \mathrm{C}-45 \mathrm{~min}$; d $-380^{\circ} \mathrm{C}, 60 \mathrm{~min}$ (SEM); e $-350^{\circ} \mathrm{C}, 5 \mathrm{~min} ; \mathrm{f}-350^{\circ} \mathrm{C}$, $20 \mathrm{~min} ; \mathrm{g}-300^{\circ} \mathrm{C}, 5 \mathrm{~min} ; \mathrm{h}-300^{\circ} \mathrm{C}, 20 \mathrm{~min} ; \mathrm{k}-300^{\circ} \mathrm{C}, 30 \mathrm{~min}$ (SEM). 
determined (Fig. 1e). Large fields of untransformed austenite have been observed in the matrix. At the holding time increasing to 20 minutes transformation has reached all austenite volume (Fig. 1f). Further holding time increasing within interval 20-120 minutes did not lead to substantial change of austenitebainite structure. Bainite sheaves consist of elipsoidal subunits. This morphology is typical for upper bainite.

After 5 minutes holding at $300^{\circ} \mathrm{C}$ the mixture of bainite, austenite and martensite has been observed (Fig.1g). Bainite has been formed around and between adjacent graphite nodules. Nucleation of bainite sheaves in austenite-graphite interface has been fixed. It should be noted, that martensite formation has not been observed at the initial stage of reaction at higher austempering temperature. This structure formation is a result of carbon diffusion deceleration and, respectively, unsufficient stabilisation of austenite at the short time of austempering. Austempering time increasing to 20 minutes leads to dramatical decreasing of untransformed austenite volumes (Fig. 1h). Further austempering time increasing from 20 to 120 minutes did not lead to essential alterations of matrix structure. New phase formation in the austenite grain boundaries at all holding times is substantial pecularity of bainite reaction at $300^{\circ} \mathrm{C}$ (Fig. $1 \mathrm{k}$ ). On the base of regularities of bainite transition in steels [1], it could be suggested that this new phase is bainitic ferrite. Nucleation at low-energetical defects such as grain boundaries is possible at high value of thermodynamical driving force [2], which increases due to austempering temperature falling. At this temperature bainitic $\alpha$-phase has had plate-like morphology (Fig. 1k).

\section{X-RAY DIFFRACTION INVESTIGATION}

X-ray diffraction (XRD) analysis has been realised on the polished specimens with DRON-3M diffractometer using monocromatic $\mathrm{Fe}_{\mathrm{K} \alpha}$ radiation at $20 \mathrm{kV}$ and $20 \mathrm{~mA}$. The austempered specimens have been ground for about $1 \mathrm{~mm}$ for the decarburised surface removing and has been polished with diamond paste. Quantitative diffraction investigation has been done with velocity $(1 / 8)^{0}$ per minute. Lattice parameter (a $\gamma)$ was calculated from the angle of peak $\gamma(111)$ measurement. The X-ray scanning has been realised five times for each of three perpendicular sides of specimen and an average has been taken. The volume fraction of untransformed austenite has been calculated by the ratio of integral intensity of $\gamma(111)$ and $\alpha(011)$ peaks [3].

Austenite carbon content was calculated according to equation [3]:

$$
\mathrm{C} \gamma=(\mathrm{a} \gamma-3.555) / 0.044
$$

where a $y$ - austenite lattice parameter.

Some pecularities of austempered ductile iron (ADI) structure formation has been determined by qualitative XRD analysis. It was found at each austempering temperature, that additional diffraction peaks exist in $2 \theta$ range $63-85^{\circ}$. These diffraction peaks was identified as $\gamma(002)$ at $2 \theta \sim 63-64^{\circ}$ and $\alpha(002)$ at $2 \theta 81-83^{\circ}$. The one of diffraction peaks at $2 \theta \sim 63-64^{\circ}$ placed at lower angle $2 \theta$ correspondes to austenite enriched by carbon due to its repartitioning during the bainite transition and another one - correspondes to unreacted austenite. Additional diffraction peaks $\alpha(002)$ could be dealed with formation of martensite small amount during water quenching to room temperature or heterogeneous carbon distribution in initial austenite which have been partially inherited by $\alpha$-phase during transformation.

The $\gamma(111)$ and $\alpha(011)$ peaks have been overlapped at any austempering temperature. Degree of overlapping decreases with austempering time increasing at any temperature. This is because relaxation processes such as redistribution of carbon between $\alpha$ - and $\gamma$-phases and tempering of $\alpha$-phase during isothermal holding have taken place. Austempering temperature decreasing leads to stronger overlapping of $\gamma(111)$ and $\alpha(011)$ peaks. Analysis of $\alpha(011)$ peak shows that the $\alpha$-phase body centered lattice has had tetragonality at all time-temperature parameters of austempering.

The untransformed austenite volume (UAV) vs. austempering time is presented in Fig. 2 . At $300^{\circ} \mathrm{C}$ and $350^{\circ} \mathrm{C}$ main amount of austenite has transformed during 15-20 minutes of austempering. Then reaction has stopped and amount of untransformed austenite has became $\sim 18 \%$ and $\sim 30 \%$ at $300^{\circ} \mathrm{C}$ 
and $350^{\circ} \mathrm{C}$ respectively. At $380^{\circ} \mathrm{C}$ the initial position of "time window"1 is $45-60$ minutes of isothermal holding. In the scope of "time window" at $380^{\circ} \mathrm{C}$ amount of untransformed austenite $(-23 \%)$ is larger than at $300^{\circ} \mathrm{C}$, but smaller than at $350^{\circ} \mathrm{C}$. It could be explained by reducing of carbon diffusion at $350^{\circ} \mathrm{C}$. At the same time, transformation driving force increases due to lowering of austempering temperature from $380^{\circ} \mathrm{C}$ to $300^{\circ} \mathrm{C}$. This compensates reducing of carbon diffusion. It is evident that transformation temperature decreasing leads to overall transformation kinetics accelerating. The same effect was observed for the case of $300 \mathrm{M}$ steel where carbide formation supressed due to alloying [1].

Austenite lattice parameters (ALP) vs. austempering time is presented in Fig. 3 . At $300^{\circ} \mathrm{C}$ and $350^{\circ} \mathrm{C}$ its increasing during $I$ stage of reaction correspondes to rising of carbon content in austenite on 0.58 and 0.65 weigth percent respectively. In "time window" interval enrichment of austenite by carbon on 0.18 and 0.20 weigth percent respectively has been found. At $380^{\circ} \mathrm{C}$ formation of $\alpha$-phase crystalls during I stage of reaction has caused enrichment of austenite by carbon on 0.7 weigth percent due to faster diffusion of carbon. Then redistribution of carbon was restricted, that is why in the scope of "time window" austenite was enriched by carbon only on 0.04 weigth percent. The monotonous rising of austenite lattice parameter has shown that in this case carbide did not formed during bainite reaction at any temperature of austempering. Comparing of UAV and ALP dependences has shown that carbon redistribution determines of overall transformation kinetics. But it is clear from presented data that more intensive carbon redistribution has decelerated bainite transformation kinetics due to austenite stabilization (by carbon enrichment) on the I stage of reaction.

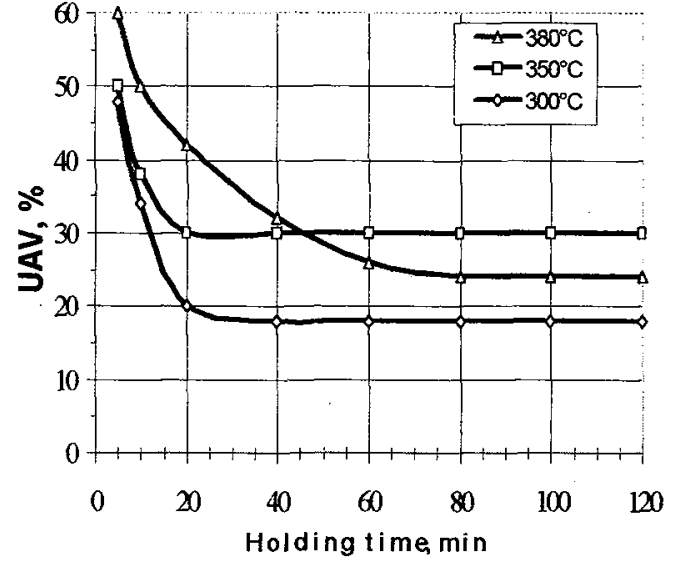

Fig. 2 UAV vs hoding time

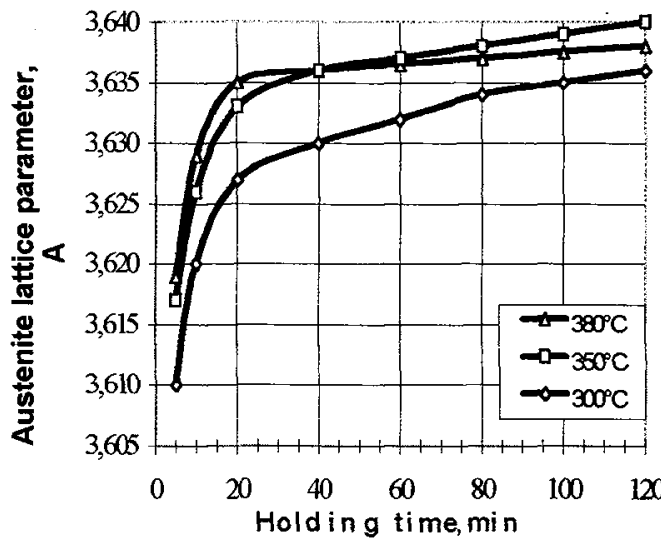

Fig. 3 Austenite lattice parameter vs. holding time

Discussed above fact of $\alpha$-phase tetragonality was studied quantitatively. Lattice parameters $\mathbf{c}, \mathbf{a}$ was calculated according to diffraction peaks $\alpha(011), \alpha(002)$ positions and an average was taken. Carbon content in $\alpha$-phase was calculated by equation [4]:

$$
\mathbf{c} / \mathbf{a}=1+0.044 *(\% \mathrm{C})
$$

where $\mathbf{c}, \mathbf{a}$ are $\alpha$-phase lattice parameters

Dependences of tetragonality parameter (c/a) and carbon content vs. holding time at each transformation temperature are presented in Fig. 4 and Fig. 5, respectively. At $380^{\circ} \mathrm{C}$ and $350^{\circ} \mathrm{C}$ tetragonality decreasing in the time interval 5-30 minutes (from 1.011-1.012 to 1.007-1.008) correspondes to dropping down of carbon content in $\alpha$-phase on $0.10-0.12$ weigth percent (from 0.25 0.27 to $0.15-0.17 \%$ ). Further austempering time increasing leads to slower decreasing of tetragonality and carbon content in $\alpha$-phase up to values 1.006 and $0.11 \%$ respectively at 120 minutes. When transformation temperature falls to $300^{\circ} \mathrm{C}$ both discussed parameters also monotonous decrease, but

1 "Time window" is a period of a relative stability in which the growth of ferrite plates ceases and amount of retained austenite stills constant. 


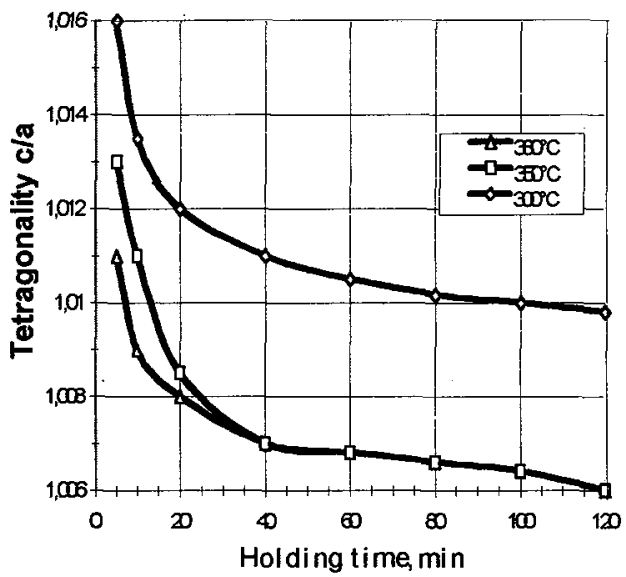

Fig. 4 Bainitic ferrite tetragonality vs holding time

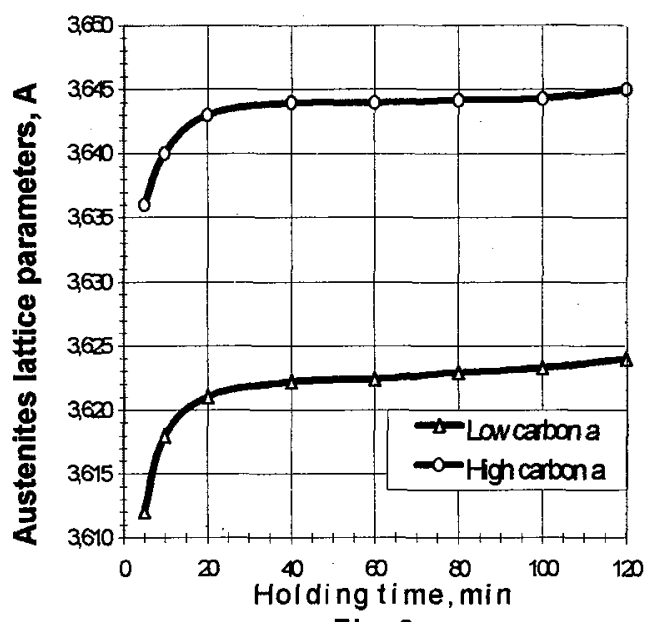

Fig.6a

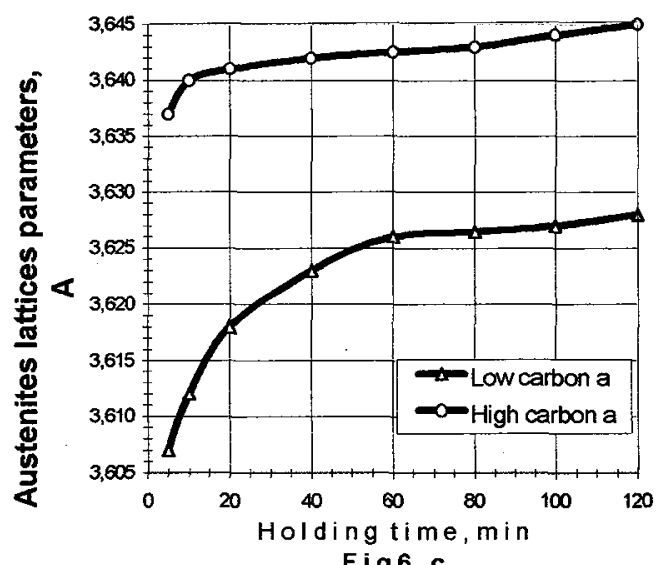

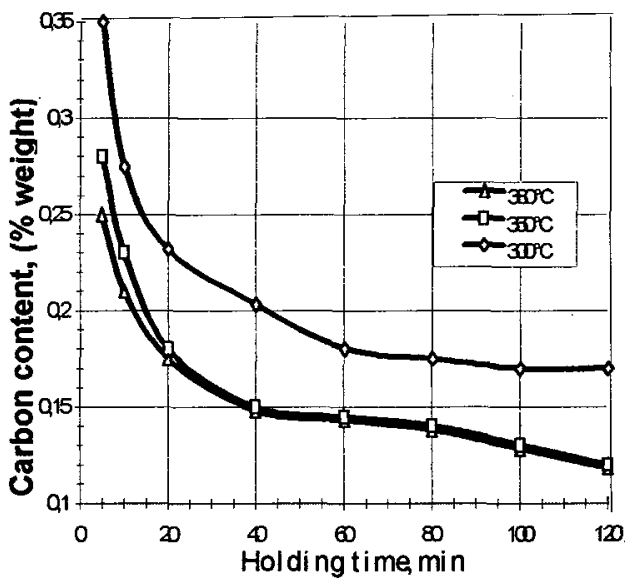

Fig. 5 Carbon content in bainitic ferrite vs holding time

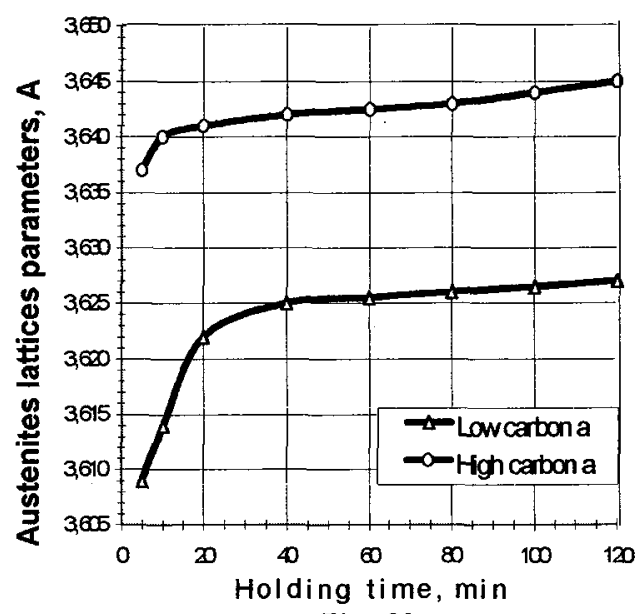

Fig.6b

Fig.6. Low and high carbon austenites lattices parameters vs. holding time

a- at $380^{\circ} \mathrm{C}$; b- at $350^{\circ} \mathrm{C}$;

$c$ - at $300^{\circ} \mathrm{C}$; 
their values at each time point increase in $\sim 1.5$ times comparing with higher temperatures. These results are in a good accordance with ALP dependences.

It was concluded above that additional diffraction peaks at $2 \theta=63-64^{0}$ corresponde to $\gamma(002)$ and its formation is dealed with unhomogeneous redistribution of carbon during bainite reaction development. According to this conclusion kinetics of high and low carbon austenites lattice parameters has been studied. Both austenites lattice parameters were calculated from the double peak $\gamma(002)$. Dependences of both austenites lattice parameters vs. holding time at each transformation temperature are presented in Fig.6. It is evident from experimental data that most intensive rising of low carbon austenite lattice parameter observed during time interval 5-20 minutes at any transformation temperature. In the case of mentioned interval, values of low carbon austenite lattice parameter have decreased with transformation temperature falling from 380-350 to 380 .

However, when holding time increases from 20 to 120 minutes low carbon austenite parameter rises more intensive at the lower temperature. Their values are : $3.623 \mathrm{~A}$ at $380^{\circ} \mathrm{C}, 3.626 \mathrm{~A}$ at $350^{\circ} \mathrm{C}$ and $3.628 \mathrm{~A}$ at $300^{\circ} \mathrm{C}$ after 120 minutes holding. This is in a good correspondence with ALP dependences (Fig.3). High carbon austenite lattice parameter abruptly increases during first 5 minutes of isothermal holding at any temperature and reaches value $\sim 3.646 \ldots 3.647 \mathrm{~A}$. Further isothermal holding within interval 5-120 minutes promotes slight increasing of high carbon austenite lattice parameter up to $3.644 . .3 .645 \mathrm{~A}$. So, alteration of high carbon austenite lattice parameter are shown less sensitivity to transformation temperature change.

The structural positions of both austenites are the subject of up-to-date discussion. However, it is well known that each bainite sheaf consists of «subunits" which have the same crystallographic orientation and this individual «subunits» are separated (along most of their interfaces) by thin films of austenite[5,6]. These thin films of austenite are isolated by the surrounding $\alpha$-phase "subunits». It could be suggested that in such case films of austenite will be able to enriching by carbon to higher concentration then blocky untransformed austenite regions, because diffusion distance from $\alpha$-phase to

films of austenite is much shorter. So, on our opinion, high carbon austenite locates within bainite sheaves and low carbon austenite correspondes to blocky austenite. This suggestion is in a good accordance with Bhadeshia results [1]. Small sensitivity of high carbon austenite lattice parameter to transformation temperature changes could be explained as following :diffusion distance from $\alpha$-phase to films of austenite is small and carbon redistribution so fast that variation of carbon diffusion rate versus temperature has had a little effect to the quantity of carbon jumped to austenite films and, respectively, to lattice parameter.

\section{CONCLUSIONS}

Therefore it has been demonstrated that there are no carbides in both upper and low bainitic matrix. Low and upper bainite morphologies are different and for low bainite $\alpha$-phase formation in initial austenite grain boundaries has been fixed. It is necessary to take into account that in upper bainite temperature region holding temperature has to be optimal to prevent strong decreasing of overall transformation kinetics due to austenite phase stabilisation by carbon. Also it has been found that there are two austenites in bainitic matrix with different lattice parameters and, respectively, different carbon content. Kinetics of austenites lattice parameters has been studied and it was found that high carbon austenite lattice parameter is less sensitive to transformation temperature change.

\section{References}

1. Rees G.I., Bhadeshia H.K.D.H., Mat. Sci. \& Tech. 8 (Nov. 1992) 985-993.

2. Olson G.B.. "Mechanisms of first-order lattice-distortive transformations", 6th International Conference on Martensitic Transformations., Sydney, Australia, 3-7 July 1989., B.C.Muddle Eds. (Trans Tech Publications, Switzerland, 1990) pp.89-100.

3.Wilson F.R., Harding R.A., BCIRA Journal 32 (Sept. 1984) .318-331.

4. Oman E., Journ. of the Iron a. Steel Inst. 123 (1931), №1, 445

5. Bhadeshia H.K.D.H., Christian J.W., Metall.Trans. 21A (1990) 767-797.

6.Christian.J.W., Edmonds D.V., Phase Transformations in Ferrous alloys (TMS-AIME, Warrendale, PA, 1984) pp. 293-327, , 